\title{
Carcinoma Papilífero da Tiveóide: Uma Hidra de Sete Cabeças?
}

\section{editorial}

A RIQUíssima Mitologia Grega inclui, entre os doze trabalhos de Héracles (Hércules em Roma), a destruição do monstro de sete cabeças, a Hidra de Lerna, o qual após a presumida morte de uma de suas unidades cerebrais, a fazia renascer, tornando a eliminação deste multicefálico animal quase impossível. Pois à custa de muito esforço, usando sua possante clava e utilizando fogo, Héracles venceu a Hidra.

Em Medicina e, especialmente em Oncologia, existe um paralelismo entre os tumores malignos e a Hidra, pois, muitas vezes, eliminada uma "cabeça" do tumor, vamos ver renascer, no mesmo local ou alhures, o conjunto de células malignas, constituindo a metástase. Para muitos tumores da linhagem endócrina é extremamente importante saber, quando se analisa o tumor primitivo, qual a possibilidade de o considerarmos de bom ou mau prognóstico, baseando-se em análise de comportamento de pacientes com o mesmo tipo de tumor, ou nos baseando em sofisticadas técnicas em busca de indícios mais definidos de eventual comportamento agressivo das células tumorais.

No caso específico da glândula tireóide, os carcinomas diferenciados podem ser divididos em dois tipos principais, isto é, o carcinoma papilífero e o carcinoma folicular. A maioria dos patologistas está de acordo em aceitar que existem variantes do carcinoma papilífero, tanto do ponto de vista morfológico como no ponto de vista evolutivo (agressividade). Schlumberger e Pacini (1), o primeiro de Villejuif (França) e o segundo de Pisa (Itália), comentam que o carcinoma papilífero pode ser considerado como microcarcinoma quando de diâmetro menor de $10 \mathrm{~mm}$, com características clássicas no exame patológico, geralmente encapsulado podendo ser detectado sem que houvesse prévio diagnóstico durante a vida, em 5-30\% dos estudos realizados em autopsias. Com o uso mais freqüiente e generalizado de ultra-sonografia seguida de punção biopsia do nódulo, este tipo de tumor relativamente benigno pode ser retirado por cirurgia e tem prognóstico excelente.

Tumores presentes em nódulos maiores, clínica e ecograficamente detectáveis, constituem-se em cerca de 70\% dos carcinomas papilíferos, geralmente parcialmente encapsulados, raramente císticos ou necróticos e muitas vezes encontrados bilateralmente (em ambos os lobos). Freqüentemente os carcinomas papilíferos, principalmente os de maior diâmetro, podem invadir os gânglios linfáticos cervicais.

As variantes do carcinoma papilífero são objeto de um excelente trabalho neste número dos "Arquivos", de autoria de Lima e colaboradores (2), da Disciplina de Endocrinologia da Faculdade de Medicina do Triângulo Mineiro. Na introdução deste trabalho, os autores, resumidamente, comentam sobre as variantes do carcinoma papilífero. Usando-se de critérios clínicos e patológicos, pode-se reconhecer que a variante folicular do carcinoma papilífero é de evolução mais grave, encontrada em adultos jovens, patologicamente exibindo características nucleares de papilífero em um padrão folicular. Curiosamente, $21 \%$ de todas as crianças e adolescentes com diagnóstico de carcinoma papilífero, detectadas após o acidente de Chernobyl, apresentavam a variante folicular (3).

A variante esclerosante difusa é, também, encontrada em crianças e jovens adultos, com metástases em linfonodos cervicais em quase todos os
Geraldo Medeiros-Neto

Professor Adjunto de Medicina, Chefe da Unidade de Tireóide, Disciplina de Endocrinologia, Hospital das Clínicas, Faculdade de Medicina da Universidade São Paulo, SP. 
pacientes. Mais rara, a variante de células altas e a variante de células colunares são próprias de indivíduos idosos, apresentando, com freqüência, citoplasma oxifilico. Lima e co-autores (2) procuraram, em seu trabalho, correlacionar os dados histopatológicos definidos, de forma sucinta, acima, com alterações moleculares no processo tumorigênico. Assim, fatores de crescimento e produtos de transcrição e tradução de oncogenes foram analisados em 32 pacientes com diagnóstico de carcinoma papilífero, sendo onze casos com diagnóstico de microcarcinoma (encapsulados e de excelente prognóstico), treze pacientes com variante folicular ou clássica (de prognóstico intermediário) e oito casos com variante de células altas e células colunares, com prognóstico pior e maior agressividade. Confirmando achados de outros autores, a presença (por método histoquímico) da fosfoproteína p53 foi detectada na variante de pior prognóstico, embora também pudesse ser encontrada em menos de $10 \%$ de outras modalidades de carcinoma papilífero. Igualmente notaram os autores que a positividade para a proteína bcl-2 eleva-se, progressivamente, nas variantes de prognóstico intermediário e de maior agressividade (células altas/colunares). A histoquímica positiva para o receptor de TSH, o fator de crescimento e transformação $ß$ (TGF-ß), o fator de crescimento epidérmico (EGF) e $\mathrm{o}$ antígeno $\mathrm{K}_{1}-67$ (MIB-1) tiveram limitado poder descriminativo quanto ao prognóstico e agressividade. $\mathrm{O}$ trabalho de Lima e seus colaboradores (2) tem o mérito de confirmar os dados recentemente publicados por pesquisadores da Clínica Mayo, Lloyd et al. (4) que documentaram a presença de TGF- $ß$ e seu respectivo receptor $\mathrm{K}_{1}-67$ (MIB-1) e p27 em carcinomas papilíferos.

Em nosso meio, Nascimento e colaboradores (5) demonstraram que uma proteína ligadora (a $B$ galactosídeo), denominada galectina 3 , mostra-se presente em 78,5\% dos Ca foliculares e 82,0\% dos Ca papilíferos. Por outro lado, em casos de carcinoma de células de Hürthle, a positividade foi de $59,1 \%$ comparativamente a $7,1 \% \mathrm{em}$ adenomas de Hürthle. Estes achados foram comentados em editorial indicando se tratar de forma promissora de distinguir-se, na patologia de Hürthle, os tumores benignos de malignos (6). Por outro lado, o grupo liderado pela Dra. Edna Kimura indicou que o RNA mensageiro de galectina 3 estaria expresso tanto em carcinomas como em adenomas foliculares, não permitindo diferenciar ambas as lesões. No caso de Ca papilífero, o RNA da galectina 3 estaria presente em $100 \%$ dos tecidos examinados (7).

Muito recentemente, Boelaert e cols. (8) indicaram que dois novos marcadores seriam candidatos potenciais quanto ao prognóstico de tumores diferenciados da tireóide: o gene transformador de tumor hipofisário (PTTG) e o fator de crescimento de fibro- blastos (FGF-2). Ambos marcadores se mostraram hiperexpressos em carcinomas da tireóide e potenciais indicadores de invasão de linfonodos e metástases (FGF-2) bem como com a possibilidade de recidiva (PTTG).

Como conclusão, podemos dizer que estamos avançando no diagnóstico molecular de carcinomas diferenciados de tireóide. Não se pode dizer que chegamos ao marcador ideal, mas a combinação de estudos histoquímicos aliados a técnicas de detecção de RNAm de genes envolvidos na tumorigênese, poderá, sem dúvida, nos indicar o grau de possível agressividade de determinado tumor, o eventual prognóstico e, mais importante, orientar a terapêutica de acordo com os novos dados obtidos.

\section{REFERÊNCIAS}

1. Schlumberger M, Pacini F. Thyroid tumors. Nucleon: France, 1999.

2. Lima MA, Maito Filho LC, Almeida HC, Santos MC, Borges MF. Caracterização molecular das variantes do carcinoma papilífero de tiróide. Arq Bras Endocrinol Metab 2003;47/3:237-242

3. Furmanchuk NA, Averkin JI, Egloff B, Ruccti C, Abelin T, Schappi W, et al. Pathomorphological findings in thyroid cancers of children from Belarus: a study of 86 cases occurring between 1986 and 1991. Histopathology 1992;21:401-8.

4. Lloyd RV Ferreiro JA, Jin L, Sebo TJ. TGFB receptors, Ki-67 and p27Kip 1 expression in papillary thyroid carcinomas. Endocr Pathol 1997;8:293-300.

5. Nascimento MCPA, Bisi $H$, Alves $V A F$, Longatto-Filho A, Kanamura CT, Medeiros-Neto $G$. Differential reactivity for galectin-3 in Hürthle cell adenomas and carcinomas. Endocr Pathol 2002; 12(3):275-9.

6. Lloyd RV. Distinguishing benign from malignant thyroid lesions: galectin 3 as the latest candidate (Editorial). Endocr Pathol 2002; 12(3):255-7.

7. Martins L, Matsuo SE, Ebuna KN, Kulcsar MAV, Friguglieti CUM, Kimura ET. Galectin messenger ribonuclei acid and protein are expressed in benign's thyroid tumors. J Clin Endocrinol Metab 2002;87:4806-10.

8. Boelaert K, McCabe CJ, Tannahill LA, Gittoes NJL, Holder RL, Watkinson JC, et al. Pituitary tumor transforming gene and Fibroblast Growth Factor-2 expression: potential prognostic indicators in differentiated thyroid cancer. J Clin Endocrinol Metab 2003;88:2341-7.

\section{Endereço para correspondência:}

Geraldo Medeiros-Neto

Unidedade de Tireóide, Disciplina de Endocrinologia

Hospital das Clínicas, Faculdade de Medicina-USP

Av. Enéas C. Aguiar, $255-8^{\circ}$. A, bloco 3

05403-900 São Paulo, SP

Fax: (011) 3031-5194

e-mail: medneto@uol.com.br 